$\S=$

\title{
Exploring Underpinning of Outsourcing Success: A case of Mul- tinational Automotive group in Malaysia
}

\author{
Kashif Latif ${ }^{1}$, Mohd Nazari Ismail ${ }^{2}$, Mohammad Nazri ${ }^{3 *}$, Mohd Roslan Mohd Nor ${ }^{4}$, Muhammad Imran Qureshi ${ }^{5}$ \\ ${ }^{1}$ Department of Business Strategy and Policy, University of Malaya, Kuala Lumpur Malaysia \\ ${ }^{2}$ Professor, Department of Business Strategy and Policy, University of Malaya, Kuala Lumpur Malaysia, \\ ${ }^{3}$ Senior Lecturer, Department of Business Strategy and Policy, University of Malaya, Kuala Lumpur Malaysia \\ ${ }^{4}$ Associate Professor, Department of Islamic History and Civilization, University of Malaya, Kuala Lumpur Malaysia \\ ${ }^{5}$ Senior Lecturer, Malaysian Institute of Industrial Technology, University of Kuala Lumpur, Malaysia \\ *Corresponding author E-mail: nazrry@um.edu.my
}

\begin{abstract}
This study explored underpinning of outsourcing success by analyzing different theories of outsourcing. This study is unique in its nature as it used interpretive paradigm to explore, analyze outsourcing success theatrically by comparing different phases of outsourcing, then the case of Boeing analyzed in the context of outsourcing and after that come up with real time case study of one big automotive group operating in Malaysia through using semi structured interview by developing and comparing themes of this study. This study figured out that cost reduction and efficiency can be attained by creating economies of scale, using and managing vendors appropriately with the combination of efficient strategic alliance.
\end{abstract}

Keywords: Exploratory Underpinning, Outsourcing Success, Interpretive Paradigm, Cost Reduction, Efficiency, Economies of Scale.

\section{Introduction}

There are several different definitions of outsourcing. In all cases, outsourcing requires third party

Involvement (1). It had been depicted that "Outsourcing signifies the delivery of products or services by an external provider - that is, one outside the boundaries of the firm" (2). Whether to outsource or not is a strategic decision, that is, to buy in products or services or produce inside the company (3). Every organization outsources. They diverge only in the span and extent of what they procure as goods and services from outside entities. Outsourcing can decipher many problems, but is also laden with hidden costs and risks, the choice of whether to outsource, in a supply chain or any other setting, is thus not about a yes or a no, but an affair of scope and extent (4). KPMG survey revealed that the processes for which the most percentage of respondents would be mounting their outsourcing were "application development and maintenance" (48\%) and "finance and accounting" (40\%) (5).

There are three key reasons why organizations in Europe outsource which are cost reduction, efficiency

improvement and reduction in headcount. This has been the tendency over the past years. Organizations lay considerations on the cost-related factors when they want to improve on their financial eminence as well as cost efficiency. Numerous researches have previously identified cost savings and strong financial base as leading drivers of outsourcing (6-12). Certainly, in the era of hyper-competition, where the basis of competition changes persistently, outsourcing has emerged as a strategic stipulation which can be gauged by the increasing size of the outsourcing industry. The outsourcing phenomenon has been ever more getting concentration both from academic and practitioner communities. The result of the research has escort towards the emergence of numerous process frameworks illustrating the phases of the outsourcing process. It is generally accepted that the outsourcing process consists of the preparation, vendor(s) selection, transition, management of relationship, and reconsideration phases. Each of the phases has been wrecked down in the series of activities that an outsourcing company performs. At the same time, the phases were subject to a stream of theoretical explanations. The studying of the outsourcing phenomenon has been stranded in many theories. Some of them are harmonizing, the other are incongruous (13). Outsourcing is the process of institute and managing a contractual relationship with peripheral vendor/supplier for the stipulation of capacity that has previously been provided in-house (14). The outsourcing process is a multifaceted structure consisting of several activities and sub activities, carrying many managerial dilemmas. It is no conjecture that many theories have been utilized to help the academics to comprehend the nature of those activities, and to help practitioners successfully manage the process. It is a common acquaintance that each phenomenon can be explained by several frameworks that are entrenched in various theoretical approaches. From its happening, the outsourcing has been approached by different theories. This creates confusion among the researchers of the outsourcing phenomenon. Several authors acknowledged considerable number of theories that could explain the outsourcing phenomenon $(15,16)$. The significant shortcoming of contemporary research is, since outsourcing of components, even mission-critical ones, has become a key strategic initiative for numerous companies, and has been described as a necessity for many firms in today's environment (17). In this stratum, it had been depicted that outsourcing governance structures are "still immature (or) lacking altogether", 
making the achievement of "cost savings and other benefits difficult to obtain" (18).

Automotive industries are accepted as the heart to bridge nations development through high rate of

Employment and are fascinated many direct investment by the global automakers (19). The Challenges for the Malaysian automotive industry depends on shifting of the global competitive strategy from efficient and superior product. Since the Malaysian automotive industry have the problem to compete in the efficiency and attractive price as compared to other carmakers. Thus Malaysian automotive manufacturing companies need to concentrate on their core activities which involve producing and assembling cars to align their outsourcing strategy (20). Hence this study seeks to find out what is the outsourcing strategy of Malaysian automotive industry, to dig out core competencies of Malaysian automotive Industry, to determine how they define their core competencies and to explore how efficiency and cost reduction can be achieved by outsourcing context and focusing on core.

\section{Advantages of Outsourcing}

By changing fixed costs to variable costs, outsourcing may aug ment operational and financial flexibility.

Setting capacity used as payment basis, this means circumvent ownership of, say, a cargo ship or factory by using someone else's as required. In human resources as well, flexibility can be attained. The employers employ and lay off workers based on demand (or add or reduce shifts, or even make payment on a piecework basis) but they may be unable or hesitant to do this, by depicting that labor costs generated in-house are flexible to this degree. Western parts of Europe or in India do not much discuss scaling down or terminating contracts with vendor organizations as outsourcing this is rather beneficial in these geographic locations where labor laws mean firing internal employees is not easy. To better fit the outsourcing party's needs dividing asset ownership from convention releases creativity in payment scheme structuring.

As contrasting to simply moving cost around, moving tasks between people might create greater value for

the system. Due to the pooling of risk (balancing highs in some customers' needs with lows in others'), specialization and scale economies vendor seemingly enjoys superior cost structure. It would be inefficient for clients to perform all tasks themselves, so from this perspective vendor may gather tasks from across numerous clients. The benefits which can be evident in areas such as relationships (creating ingle access points to many partners or customers), receivables (achieving scale in the collections process and pooling of default risk), information (consolidation into a sole repository, thus reducing search costs), procurement, warehousing, transportation, inventory levels and capacity which is called aggregation.

\section{Disadvantages of Outsourcing}

Outsourcing increases the difficulty of communication and coordination which is perhaps the immediate

disadvantages of it. When the demeanor of the activity based on tacit knowledge critical capacity outsourcing may be put at risk. Through experience, metaphor and analogy, indirect communication this kind of knowledge can be learned rather than explicit knowledge which can usually be confined in procedures and manuals. When the activity resides in-house the chance of keeping tacit knowledge as institutional knowledge (which is sometimes called tribal knowledge) is higher. Even challenges are great such that outsourcing must be linked to great efforts to codify tacit knowledge which is at risk. Outsourcing enhances dependence on vendor which comprises to the extent for critical capabilities of present and future. Any doubts about the vendor financial stability must address from due diligence in outsourcing. As part of the request-for-quote (RFQ) and trying to verify them independently have been included in asking for financial records. Numerous organizations do not realize that investments in business controls must truly be augmented to account for new risks by associating outsourcing with reductions in resource and staff requirements. Organization might be better to not outsource at all as correct oversight of vendors may require very close involvement. Outsourcing organizations may experience resistance from in-house staff besides worrying about vendor risk. The word layoffs often come not long after the word outsourcing is expressed.

\section{Literature Review}

Literature on strategic relationships has long asserted that suitable governance is essential for the success of sourcing relationships (21-23).

\subsection{Core Competency Theory}

The concept of core competences has been developed on the foundation of the resource-based theory. It had

Been depicted that the core competencies as the communal learning in the organization, especially how to harmonize varied production skills and integrate multiple streams technologies (24). The use of concept of core competences in outsourcing became very popular among researchers. The concept has been primarily used to develop and test various outsourcing decision frameworks arguing that the core activities shall remain in house. Learning and communication grounds of the concept made it also applicable in managing relationship and reconsideration phases. Vendor's competences are tacit to be the important factors that persuade success of an outsourcing arrangement (25).

An analysis of the vendor's competencies is, according to the Core Competencies theory, the important factor that determines the success of an agreement. The Core Competencies Theory has also been employed to study the phases of relationship management and reconsideration. The Core Competencies Theory is the second most accepted approach in the academic research related to outsourcing (26). The research set out in the TCE, was published and is worth talk about at this point, given that the second theoretical pillar of the research is the Core Competencies Theory (27). It must be noted that the research of examining the phases of preparation, relationship maintenance and reconsideration, concluded that the Core Competencies Theory is one of the two approaches that better demonstrate the success factors of the outsourcing process (15).

\subsection{Resource-Based View}

The core principle of the resource-based view is that resources and capabilities can differ significantly

Across firms, and that these differences can be stable (28). If resources and ability of a firm are mixed and deployed in a proper way they can make competitive advantage for the firm. The resource-based view in outsourcing construct from an intention that an organization that lacks valuable, rare, inimitable and organized resources and capabilities, shall look for an external provider in order to overcome that weakness. Therefore the most well-known use of the theory is in the Preparation phase of the outsourcing process for defining the decision making framework and in the vendor selection phase for selecting a suitable vendor. The theory has been also utilized to elucidate some of the key issues of the Managing relationship and Reconsideration phases (13).

\subsection{Relational Theory}

The Relational Theory gives explanations on how enterprises may obtain and uphold a competitive advantage with regard to their relationships with other organizations. This model has been employed to study the phases of transition, relationship management and reconsideration. Therefore, the 
Relational Theory is the merely approach that may be applied to the investigation of all phases of the outsourcing process (26). This had been stated that the possibilities of laying the groundwork, through appropriate planning, for turning the outsourcing process from a simple partnership into a strategic alliance (29). Using the Relational Theory, they scrutinize the factors that may be used to make decisions at the phases of preparation and relationship maintenance, intend to make choices that will contribute to the creation of strategic alliances (30). They recommend a relational model aiming to analyze the effects of an organization's capability to develop a relationship with the vendor at the phases of vendor selection and relationship maintenance for the development of competitive advantage, based on technology (31). The research reached the conclusion that the benefits of the outsourcing process are determined by the quality of the relationship at its enterprise and by the care given by contracting parties to the development of the relationship.

\subsection{Knowledge Based View}

The knowledge-based view provides imminent in understanding how individuals co-operate to produce

goods and services. The knowledge-based view differentiates two ways how knowledge is shared among partners. They are knowledge creation and knowledge application. The knowledgebased view has been employed by utilizing in the outsourcing research to establish that knowledge sharing in the Managing relationship stage is positively related to the success of an outsourcing arrangement (13). The Knowledge-based View gives an understanding of how individuals cooperate to produce goods and to provide services. The Knowledge-based View ascertains two methods for knowledge-sharing among partners (32). These are knowledge generation and knowledge appliance. The Knowledgebased View applies to outsourcing in order to exhibit that knowledge-sharing at the relationship management phase of the outsourcing process is positively related to the success of the outsourcing agreement $(33,34)$. The Knowledge-based View is the underpinning of the model proposed, which attempts to explicate the management of the relationship between the two contracting parties of the outsourcing process (35). The model, which also employed the Core Competences theory, reached the conclusion that knowledge-sharing is one of the key success factors of an outsourcing process (26).

\subsection{Neoclassical Economic Theory}

The key distinctiveness of the neoclassical economic theory are (36), assumption of lucid,

maximizing behavior by agents with given predilection function, focus on accomplished, or movement towards, equilibrium states and nonappearance of chronic information problem. The neoclassical theory explicates the preliminary motives for outsourcing established by some pioneering companies like Kodak. However, the theory has received a considerable critique for not being able to explain contemporary business processes. Especially, the concepts of prudence and absence of chronic information problem have been criticized. However they showed that the neoclassical economic theory explicate critical success factors of outsourcing that are being appraise in the Reconsideration phase (15). This theory has been profoundly criticized due to its inability to explain modern business operations. In particular, the assumptions of rationalism and the absence of the chronic problem of lack of information have been censure as unrealistic and outdated. However, they established that the Neoclassical Economic Theory may be applied to explain critical success factors of the outsourcing process during the Reconsideration phase (15).

\subsection{Social Exchange Theory}

The social exchange theory elucidates interpersonal relationships by positing the economical cost benefit

analysis as prerequisite for social engagement and exchange. The theory presumes that the exchange of resources (material or social) is a fundamental form of human interaction. Social exchange is an ongoing mutual process in which actions are reliant on rewarding reactions from others (15). The Social Exchange Theory construe interpersonal transactional relationships by using the economic cost benefit analysis and efficiency as a requisite for social participation and social exchange. The theory assumes that the sharing of resources (material or social-intangible) is a fundamental form of human interaction. Therefore, Social Exchange is a continuing reciprocal process in which the actions of individuals or organizations depend on the rewarding reactions they receive from others (15). The research has been based on the Social Exchange theory and, to a lesser extent, on the TCE in order to recommend a model that interprets the phase of reconsideration during the outsourcing process (37). The Social Exchange approach has also been employed in the highly theoretical work of Gottschalk \& Solli-Sæther $(15,38)$.

\subsection{Economy of Information}

It has been divulge that the information is not ideal and new economical models come out to elucidate

situations where two parties possess unequal or none quantity of information. One of the first works in the area was advancement of the search theory (39). The classification of sellers and the discovery of their prices are only one sample of the enormous role of the search for information in economic. Another key notion of the economy of information is the concept of signaling developed by Spence (40). His essay is about markets in which signaling takes place and in which the main signalers are comparatively several and in the market adequately occasionally that they are not expected to invest in acquiring signaling reputation. Application of the economy of information in outsourcing is connected to activities of searching, selecting, and contracting the vendor. However, the economics of information hasn't been employed explicitly in the studies of the outsourcing process. After analyzing all above depicted theories our theoretical underpinning for this study is Core Competency theory. We are using this theory for our study because a theme that crop up in many modern business conversations about outsourcing is paraphraseable as "Focus on your core competencies, and outsource everything else i-e OEC." The causal premise is that focus is valuable, and outsourcing can eradicate distractions (4).

Prahalad and Hamel popularized the concept of core competency in a 1990 Harvard Business Review article $(24,41,42)$. Their core competencies, of which most firms will have no more than five or six, are defined by three key attributes, as they give potential access to a broad variety of markets, they make a considerable contribution to alleged customer benefits of the end product and they are intricate for competitors to imitate. Literature critical message is that an organization can exploit its competitive advantage by identifying its core competencies and organizing activities around them. This theme is highly suggestive of the RBV (Resource based view) (43). They suggest that the goal of outsourcing everything that is not core (44). They defined core competencies as skill or knowledge sets, not products (which can be reverse engineered) or functions (since core competencies have a propensity to cut transversely traditional functions, e.g., production, engineering, sales, finance). Flexible, long-term platforms those are proficient of adaptation or evolution, partial in number to maybe two or three (more than one, but fewer than five). They are unique sources of influence in the value chain areas where the company can govern, rudiments imperative to customers in the long run and entrenched in the organization's systems (rather than dependent upon key individuals). In the eyes of both sets of authors, core competencies 
are not "things we do very fine or very regularly," but in its place are "things that are strategically important." These are rarely restrained to individual product departments or functional areas. The detection of focus underlies Drucker's idea that outsourcing can "significantly improve the quality of the people who still work for you," by offloading tasks that insiders do not perform often enough to attain the excellence of a specialist (45).

\section{Outsourcing Strategy Comparison Between Boeing and Cummins}

\subsection{Boeing}

In 2003, Boeing publicize its new age aircraft, the 787 Dreamliner, linking considerably higher percentage

Of outsourcing than what it had used earlier (46). The intend of lower costs and faster development were belied by a chain of setbacks including delayed delivery, cost overruns, multiple "aviation incidents" on account of problematic components and grounding of the fleet by premier customers (47).

\subsection{Cummins}

Almost a decade after the launch, Boeing admitted that their outsourcing strategy had left wrong (48). In disparity, over the same time period, Cummins' decade long outsourcing arrangement with HCL receive the "Outsourcing Excellence Award", with a Director commenting that "All through our 10-year partnership, HCL has helped us attain operational efficiencies and provided access to specialty expertise, enabling us to focus on our core business" (49).

\section{Methodology}

According to Creswell (50), a qualitative approach can be used when the researcher contributes to the

knowledge based mainly on constructivist perspectives and seeks to make denotation of experiences in order to develop a pattern. The Case study is one of the methods in qualitative research in which open-ended emergent data is collected with the objective of developing themes (50). By using in-depth personal interviews, information will be implored from the management of the firms. This approach is suitable when examining current events over which the researcher has little or no control, and when the purpose of the research is to explain or explore events. The rationale of case study research is "to understand a real-life phenomenon in depth" and "contribute to our knowledge of individual, group organizational, social, political, and related phenomena" (51). It is a good tool for exploratory studies and an effectual strategy for exploring "what, why, how" questions. Case study research allows direct observation of a phenomenon in its natural setting, thus promoting deep, realistic understanding (52). This had been noted that there are three types of interviews useful for data collection in case study: unstructured, semi-structured and structured (53). The semi-structured interview characteristically has predetermined questions but interviewer has the flexibility to transform the questions and the order of the questions. The interviewer has auxiliary flexibility to omit or add questions based on interviewer's understanding of the interviewee's responses (54).

\section{Data Collection}

Based on earlier depicted rationale qualitative research has been used, as study is exploratory in nature to

dig out What, How, Why questions of outsourcing. Case study had been conducted for one Multinational Automotive group as part of Malaysian Automotive Industry, through which researcher can scrutinize contextual situation by asking open-ended questions and examining many variables that will not be feasible using other approaches (51). Semi structured interviews had been conducted which characteristically has predetermined questions but interviewer has the flexibility to transform the questions and the order of the questions. The interviewer has auxiliary flexibility to omit or add questions based on interviewer's understanding of the interviewee's responses (54).

For this case, Semi Structured interview was conducted which commenced with a set of interview themes

But were prepared to vary the order in which questions were asked and to ask new questions in the context of the research situation. Interviews had been conducted from one director and two senior managers from one multinational automotive group operating in Malaysia. All interviews were audio recorded, transcribed and analyzed. Below Codes had been assigned for three respondents.

- $\quad$ Director - R1

- Senior Manager 1 - R2

- $\quad$ Senior Manager 2 - R3

First interview with respondent R1 was of 20 minutes, R2 - 30 minutes and R3 - 30 minutes respectively. Case study company assigned code with Firm A. Age Range of Respondents was from 33 to 55 years old and there was no forced participation in the study.

\section{Results, Findings with Themes \& Conclu- sion}

Below metric devised for analyzing data and themes.

\begin{tabular}{|c|c|c|c|c|}
\hline Themes & $\mathrm{R} 1$ & $\mathrm{R} 2$ & R3 & Conclusion \\
\hline $\begin{array}{c}\mathrm{T} 1 \\
\text { Core Com- } \\
\text { petences }\end{array}$ & $\begin{array}{l}\text { Our core com- } \\
\text { petency is in } \\
\text { technology, } \\
\text { state of the art } \\
\text { production } \\
\text { facility which } \\
\text { we don't want } \\
\text { to outsource. }\end{array}$ & $\begin{array}{l}\text { We are com- } \\
\text { petent with } \\
\text { the technolo- } \\
\text { gy of the car } \\
\text { and equip- } \\
\text { ment. }\end{array}$ & $\begin{array}{l}\text { Technology } \\
\text { and Styling. }\end{array}$ & $\begin{array}{l}\text { All three } \\
\text { responses } \\
\text { are aligning } \\
\text { with each } \\
\text { other and } \\
\text { one of the } \\
\text { respondents } \\
\text { higher in } \\
\text { cadre to } \\
\text { make stra- } \\
\text { tegic deci- } \\
\text { sion said } \\
\text { that they } \\
\text { don't want } \\
\text { to outsource } \\
\text { their core } \\
\text { competen- } \\
\text { cy. }\end{array}$ \\
\hline $\begin{array}{c}\mathrm{T} 2 \\
\text { Outsourcing } \\
\text { of any } \\
\text { Function/s } \\
\text { and/or } \\
\text { processes }\end{array}$ & $\begin{array}{l}\text { We outsource } \\
\text { activity/function } \\
\text { of accounts and } \\
\text { tax. We also } \\
\text { outsource logis- } \\
\text { tics. Other } \\
\text { outsourcing } \\
\text { activity in- } \\
\text { volves metal } \\
\text { sheets, radio } \\
\text { system, lights } \\
\text { and other com- } \\
\text { ponents of the } \\
\text { car. }\end{array}$ & $\begin{array}{l}\text { We out- } \\
\text { source com- } \\
\text { ponents of } \\
\text { the car such } \\
\text { as audio } \\
\text { system, } \\
\text { leather seats, } \\
\text { lights, GPS } \\
\text { system, etc. }\end{array}$ & $\begin{array}{l}\text { Accounts, } \\
\text { taxes and } \\
\text { logistics. }\end{array}$ & $\begin{array}{l}\text { Their out- } \\
\text { sourcing } \\
\text { function is } \\
\text { aligned with } \\
\text { the result of } \\
\text { KPMG, as } \\
\text { they re- } \\
\text { vealed that } \\
\text { second most } \\
\text { process to } \\
\text { be out- } \\
\text { sourced is } \\
\text { Finance and } \\
\text { Accounting } \\
40 \% \text {. }\end{array}$ \\
\hline $\begin{array}{c}\mathrm{T} 3 \\
\text { Driving } \\
\text { Forces for } \\
\text { Outsourcing }\end{array}$ & $\begin{array}{l}\text { Driving force is } \\
\text { to attain effi- } \\
\text { ciency and cost } \\
\text { reduction. Our } \\
\text { strategy is to } \\
\text { build vendors } \\
\text { on core compe- } \\
\text { tency means } \\
\text { whoever expert } \\
\text { in particular }\end{array}$ & $\begin{array}{l}\text { We out- } \\
\text { source to } \\
\text { improve our } \\
\text { quality and } \\
\text { control the } \\
\text { cost. }\end{array}$ & $\begin{array}{l}\text { To be more } \\
\text { competitive } \\
\text { among the } \\
\text { other car } \\
\text { manufactur- } \\
\text { er in terms } \\
\text { of cost and } \\
\text { quality. }\end{array}$ & $\begin{array}{l}\text { Firm A is } \\
\text { using core } \\
\text { competency } \\
\text { concept for } \\
\text { outsourcing } \\
\text { as whoever } \\
\text { have core } \\
\text { competency } \\
\text { in their } \\
\text { respective }\end{array}$ \\
\hline
\end{tabular}




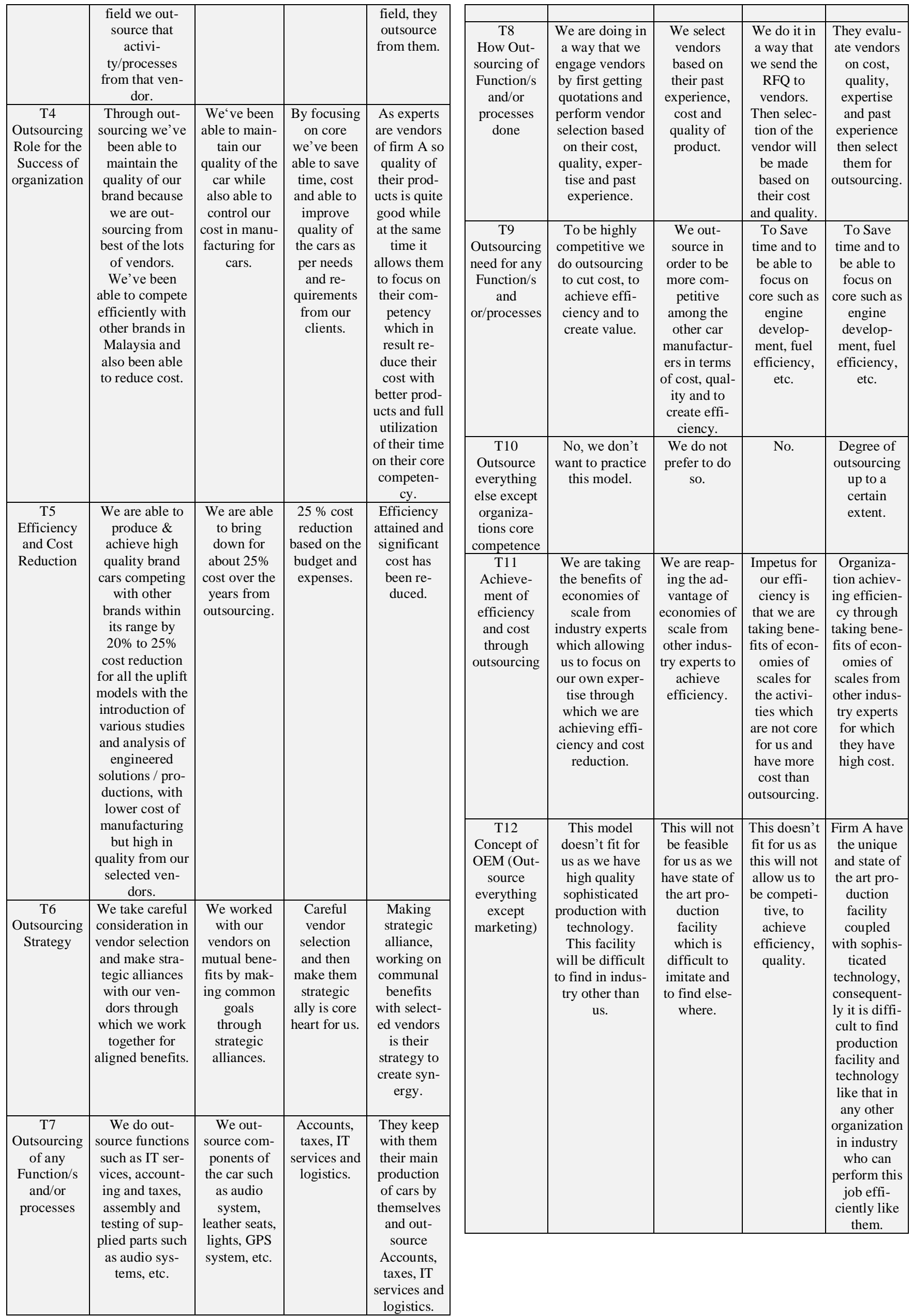




\section{Contribution of Study}

It is expected that this case study will contribute towards the success of business by achieving cost reduction and efficiency through outsourcing strategy which fills the gap that exists in the literature, thus enabling participants to make more informed decisions in future. This study is exploratory in nature on the phenomenon of outsourcing and through this inductive approach theory can be built for further analysis and studies. In natural setting more in depth study has been conducted which is difficult to obtain in other setting. This study revealed that by employing core competence concept economies of scales can be achieved.

\section{Conclusion}

In conclusion, outsourcing is a business strategy used by companies, for reasons such as the lack of expertise, through the subcontracting of their business functions to outside organizations. Outsourcing is receiving much response from companies all around the world these days, with large amount of European companies already using it for reason such as to seek cash infusion, reduce risk and operating costs, etc. Companies that offer services at low prices can be easily found. However, due to several ethical concerns, some companies prefer the costlier route as the price difference could be deceptive because the variation will only be in the initial cost. Compromise of customer data and vendor reliability are one of the main ethical concerns companies tend to face.

Outsourcing is not the right tool for ever job but it is a good tool for the right job. There are a couple of typical and traditional problems faced in outsourcing. Poor planning and less-than-expected results are some of the problems faced by outsourcing players. There are solutions to these problems however, there is no silver bullet and some situations can never be predicted. All in all, the future of outsourcing appears to be fairly bright and positive. The automotive industry enables new outsourcing players to take advantage of the different stages of an organization's value chain. Besides that, there are also clear signs indicating the broadening confidence in the outsourcing industry, which would ultimately lead to more companies adopting the business strategy over an increasingly wide range of business processes and functions.

\section{References}

[1] P. Klaas Jagersma and D. M. van Gorp, "Redefining the paradigm of global competition: offshoring of service firms," Business strategy series, vol. 8, pp. 35-42, 2007.

[2] M. Stephan and M. Silvia, "A dynamic perspective on nextgeneration offshoring: The global sourcing of science and engineering talent," The Academy of Management Perspectives, vol. 22, pp. 35-54, 2008.

[3] I. R. Edvardsson, G. K. Oskarsson, and S. Vesteinsdottir, "Enhancing customer services and core competencies: outsourcing in Icelandic service SMEs," International Journal of Entrepreneurship and Small Business, vol. 14, pp. 313-333, 2011.

[4] A. A. Tsay, Designing and controlling the outsourced supply chain: Now Publishers Incorporated, 2014.

[5] P. Fersht and J. Snowdon, "State of the Outsourcing Industry 2013," 2013.

[6] O. F. Bustinza, L. M. Molina, and L. J. GUTIERREZ- GUTIERREZ, "Outsourcing as seen from the perspective of knowledge management," Journal of Supply Chain Management, vol. 46, pp. 23-39, 2010.

[7] B. Ghodeswar and J. Vaidyanathan, "Business process outsourcing: an approach to gain access to world-class capabilities," Business Process Management Journal, vol. 14, pp. 23-38, 2008.

[8] H. Hsiao, R. G. Kemp, J. Van der Vorst, and S. O. Omta, "A classification of logistic outsourcing levels and their impact on service performance: Evidence from the food processing industry," International Journal of Production Economics, vol. 124, pp. 75-86, 2010.

[9] B. Jiang, G. V. Frazier, and E. L. Prater, "Outsourcing effects on firms' operational performance: An empirical study," International
Journal of Operations \& Production Management, vol. 26, pp. 1280-1300, 2006.

[10] J. R. Kroes and S. Ghosh, "Outsourcing congruence with competitive priorities: Impact on supply chain and firm performance," Journal of Operations Management, vol. 28, pp. 124-143, 2010.

[11] Sami, A., Jusoh, A., Md. Nor,K., Irfan,I., Irum, S., Qureshi, M.I., \& Ashfaq, M. (2018). Professionalism is the key to create public value International Journal of engineering and Technology, 7(3.30), 583586.

[12] B. Quélin and F. Duhamel, "Bringing together strategic outsourcing and corporate strategy:: Outsourcing motives and risks," European management journal, vol. 21, pp. 647-661, 2003.

[13] A. F. van Wagenberg, "The Netherlands: facility management in Dutch municipalities," Nordic journal of surveying and real estate research, vol. 1, 2014.

[14] Z. Perunović and J. L. Pedersen, "Outsourcing process and theories," in Proceedings of the POMS 18th Annual Conference, May 4-7, Dallas, Texas, 007, 2007.

[15] J. Momme, "Outsourcing manufacturing to suppliers," Citeseer, 2001.

[16] P. Gottschalk and H. Solli-Sæther, "Critical success factors from IT outsourcing theories: an empirical study," Industrial Management \& Data Systems, vol. 105, pp. 685-702, 2005.

[17] R. McIvor, The outsourcing process: strategies for evaluation and management: Cambridge University Press, 2005.

[18] T. Schoenherr, "Outsourcing decisions in global supply chains: an exploratory multi-country survey," International Journal of Production Research, vol. 48, pp. 343-378, 2010.

[19] T. Schoenherr, S. Narayanan, and R. Narasimhan, "Trust formation in outsourcing relationships: A social exchange theoretic perspective," International Journal of Production Economics, vol. 169, pp. 401-412, 2015.

[20] R. M. Shatouri, R. Omar, K. Igusa, and F. de São Pedro Filho, "Embracing green technology innovation through strategic human resource management: a case of an automotive company," American Journal of Economics and Business Administration, vol. 5, p. 65, 2013.

[21] N. A. A. Rahman, T. Melewar, and A. M. Sharif, "The establishment of industrial branding through dyadic logistics partnership success (LPS): The case of the Malaysian automotive and logistics industry," Industrial Marketing Management, vol. 43, pp. 67-76, 2014.

[22] J. H. Dyer and H. Singh, "The relational view: Cooperative strategy and sources of interorganizational competitive advantage," Academy of management review, vol. 23, pp. 660-679, 1998.

[23] E. Mazzola and G. Perrone, "A strategic needs perspective on operations outsourcing and other inter-firm relationships," International Journal of Production Economics, vol. 144, pp. 256-267, 2013.

[24] M. Sambasivan, L. Siew-Phaik, Z. A. Mohamed, and Y. C. Leong, "Factors influencing strategic alliance outcomes in a manufacturing supply chain: role of alliance motives, interdependence, asset specificity and relational capital," International Journal of Production Economics, vol. 141, pp. 339-351, 2013.

[25] G. Hamel and C. K. Prahalad, "The core competence of the corporation," Harvard business review, vol. 68, pp. 79-91, 1990

[26] N. Levina and J. W. Ross, "From the vendor's perspective: exploring the value proposition in information technology outsourcing," MIS quarterly, pp. 331-364, 2003.

[27] A. Vaxevanou and N. Konstantopoulos, "Models Referring to Outsourcing Theory," Procedia-Social and Behavioral Sciences, vol. 175 , pp. 572-578, 2015.

[28] U. Arnold, "New dimensions of outsourcing: a combination of transaction cost economics and the core competencies concept," European Journal of Purchasing \& Supply Management, vol. 6, pp. $23-29,2000$.

[29] J. Barney, W. Hesterly, S. Clegg, C. Hardy, and W. Nord, "Handbook of organization studies," Handbook of organization studies, 1996.

[30] L. Willcocks and C. J. Choi, "Co-operative partnership and 'total'IT outsourcing: From contractual obligation to strategic alliance?," European management journal, vol. 13, pp. 67-78, 1995.

[31] T. F. Espino-Rodriguez and M. Rodriguez-Diaz, "Effects of internal and relational capabilities on outsourcing: an integrated model," Industrial Management \& Data Systems, vol. 108, pp. 328-345, 2008.

[32] G. Giannakopoulos, P. Professor Damianos Sakas, D. Sakas, D. Vlachos, and D. Nasiopoulos, "Modelling strategic management for the development of competitive advantage, based on technology," 
Journal of Systems and Information Technology, vol. 16, pp. 187 209, 2014.

[33] N. K. Dimitrios, D. P. Sakas, and D. Vlachos, "Modeling the Scientific Dimension of Academic Conferences," Procedia-Social and Behavioral Sciences, vol. 147, pp. 576-585, 2014.

[34] K. Kutsikos and D. Sakas, "A Framework for Enabling Service Configuration Decisions: the Case of IT Outsourcing Providers," Procedia-Social and Behavioral Sciences, vol. 148, pp. 604-610, 2014.

[35] K. Kutsikos and G. Mentzas, "Managing Value Creation in Knowledge-intensive Business Service Systems," Knowledge Service Engineering Handbook, pp. 123-138, 2012.

[36] J.-N. Lee, "The impact of knowledge sharing, organizational capability and partnership quality on IS outsourcing success," Information \& Management, vol. 38, pp. 323-335, 2001.

[37] G. M. Hodgson, "Critique of neoclassical microeconomic theory," The Elgar companion to institutional and evolutionary economics, vol. 1, pp. 128-134, 1994.

[38] D. Whitten and R. L. Wakefield, "Measuring switching costs in IT outsourcing services," The Journal of Strategic Information Systems, vol. 15, pp. 219-248, 2006.

[39] P. Gottschalk and H. Solli-Sæther, "Maturity model for IT outsourcing relationships," Industrial Management \& Data Systems, vol. 106, pp. 200-212, 2006.

[40] G. J. Stigler, "The economics of information," The journal of political economy, pp. 213-225, 1961.

[41] M. Spence, "Job market signaling," The quarterly journal of Economics, pp. 355-374, 1973

[42] C. K. Prahalad and G. Hamel, The core competence of the corporation: Springer, 2006.

[43] G. Hamel and C. K. Prahalad, Competing for the Future: Harvard Business Press, 2013.

[44] R. McIvor, "How the transaction cost and resource-based theories of the firm inform outsourcing evaluation," Journal of operations management, vol. 27, pp. 45-63, 2009.

[45] J. B. Quinn and E. S. Strategy, "Strategic outsourcing: leveraging knowledge capabilities," Image, vol. 34, 2013.

[46] P. F. Drucker, Managing in a time of great change: Harvard Business Press, 2009.

[47] S. Denning, "What went wrong at Boeing," Strategy \& Leadership, vol. 41, pp. 36-41, 2013.

[48] S. Denning, "Boeing's offshoring woes: seven lessons every CEO must learn," Strategy \& Leadership, vol. 41, pp. 29-35, 2013.

[49] D. Gates, "A 'prescient'warning to Boeing on 787 trouble," The Seattle Times, 2011

[50] S. Pratap, "Towards a framework for performing outsourcing capability," Strategic Outsourcing: An International Journal, vol. 7, pp. 226-252, 2014

[51] J. w Creswell, Research design: Qualitative, quantitative, and mixed methods approaches: SAGE Publications, Incorporated, 2009.

[52] R. K. Yin, "Case Study Research: Design and Methods. 4. udgave," ed: Sage Publications, 2009.

[53] E. R. Babbie, Introduction to social research: Wadsworth Cengage learning, 2010.

[54] M. N. Saunders, M. Saunders, P. Lewis, and A. Thornhill, Research methods for business students, 5/e: Pearson Education India, 2011.

[55] C. Robson, Real world research: A resource for social scientists and practitioner-researchers vol. 2: Blackwell Oxford, 2002. 